\title{
Antibacterial Properties of Rosemary (Rosmarinus Officinalis)
}

\author{
Abdulrahman Kloy, Jamal Ahmad, Umar Yusuf*, Musa Muhammad \\ Department of Pharmacology and Therapeutics, College of Health Sciences, Usmanu Danfodiyo University, Sokoto, \\ Nigeria
}

\author{
*Corresponding Author \\ Umar Yusuf
}

\section{Article History}

Received: 06.01.2020

Accepted: 13.01 .2020

Published: 19.01.2020

\begin{abstract}
Medicinal herbs have long been used as traditional medicine to treat infectious diseases. The increasing use of synthetic antibiotics today has led to an increase in resistant strains and high side effects. In this regard, every year many researchers from this huge plant source are sending a range of secondary compounds to the consumer market for the treatment of human diseases. Therefore, the identification of herbs with antimicrobial effects can help to produce new drugs with a broad spectrum of effects. This study, based on scientific references, describes information on the antimicrobial effects of rosemary.
\end{abstract}

Keywords: Medicinal Plants, antibacterial effects, Rosmarinus Officinalis.

\section{INTRODUCTION}

One of the concerns and concerns in the biomedical and medical sciences is bacterial and fungal resistance to the extent that some of these bacteria are resistant to chemical drugs more than $90 \%$. Alexander Fleming, a well-known biologist and botanist, first examined the bacterial resistance and won the Nobel Prize in 1945 [1-3]. Nowadays, in cases where drug resistance is created by changing the drug to fight against pathogenic bacteria and fungi. On the other hand, for many years, natural remedies, especially medicinal herbs, have been the basis and even in some cases the only treatment, while their raw materials have been used in the pharmaceutical industry [4]. The advent of chemistry in the early twentieth century and the development of complex organic synthesis systems led to the development of the pharmaceutical industry and the substitution of synthetic drugs for herbal remedies [5]. But as advances in the production of new chemicals and various antibiotics began to take place, the harmful effects of these drugs gradually began to appear, and since the 1950s numerous pathogenic bacteria have shown resistance to antibiotics, which is still expanding [6]. Medicinal plants worldwide are used by indigenous populations and play an important role in treating human and animal diseases [7]. One of the major problems in antibiotic therapy today is the resistance and subsequent side effects of the drug. Accordingly, after researching the effects of plants, man has used them in various industries [8]. After the discovery of penicillin in the 40s, and its use in treatment, new antibiotics were introduced every day to treat infections [9]. The result was the expansion of the clinical use of natural and synthetic antibiotics in the treatment of clinical infections [10]. The overuse of these antimicrobial drugs has led to increased drug resistance against different antibiotics in most bacteria [11-13]. This has been one of the reasons for the growing use of herbs as low-risk, affordable, and inexpensive natural ingredients in the treatment of bacterial infections compared to synthetic antibiotics [14-16]. Also, these herbal remedies are more popular with people [17-19]. The role of natural products in drug production is increasing, not only when bioactive compounds are used directly as therapeutic drugs, but also when used as a raw material for drug synthesis, or as a model the base is used for new biologically active compounds [20-22]. Studies show that only about $10 \%$ of the 250,000 species of plants studied worldwide [23]. Therefore, the use of herbal drugs as an alternative to chemical drugs and antibiotics was investigated.

\section{Rosmarinus Officinalis}

Rosemary belongs to the Lamiacea family and is popular as a spice and medicinal plant in many countries. It has anti-bacterial, antifungal, anti-cancer, anti-diabetic, anti-inflammatory, analgesic, antioxidant and endemic effects on

Copyright @ 2020: This is an open-access article distributed under the terms of the Creative Commons Attribution license which permits unrestricted use, distribution, and reproduction in any medium for non commercial use (NonCommercial, or CC-BY-NC) provided the original author and source are credited. 
the Mediterranean and Asian region [24-28]. The Lamiacae family, or mint family, is a family of plants, shrubs and trees comprising about 200 genera and 3,200 species, many of which have a long history of drug and food use [29]. Rosemary is listed in the World Series of Weeds, but due to its popularity and therapeutic properties, it is in the top priority [30]. The antimicrobial properties of rosemary are due to phenolic compounds: carnosol, rosmarinic acid, caffeic acid, flavonoids including diosmin, luteolin, zincquanine, and monoprenes such as camphor, cineole and borneol [31]. Rosemary is resistant to water stress and can continue to grow under drought conditions [32]. Both fresh and dried rosemary leaves are used for their characteristic aroma in food cooking or in small amounts as herbal teas, while rosemary extracts are commonly used as natural antioxidants to improve shelf life. Spoiled foods are used [33]. Rosemary is one of the spices that has the highest levels of antioxidants and can help fight bacteria and cancer. Antioxidant properties of rosemary extracts vary due to genetic and growth conditions, region and geographical origin, climatic conditions, extraction process, main plant quality and date of harvest [34]. While the immune-boosting properties of the rosemary plant are sufficiently effective, the plant also works well against bacterial infections, especially those that occur in the stomach. H. pylori is a common and very dangerous pathogen or pathogen that can lead to gastric ulcer, but rosemary has been shown to help prevent it from growing. Also, rosemary is associated with the prevention of Staph infection, which kills thousands every year [35].

\section{Antibacterial Effects}

Antibacterial effects of rosemary on Gram-negative bacteria are more than Gram-positive bacteria. Which increases with increasing concentration of bactericidal property.

Table-1: The highest antibacterial effect of rosemary in studies

\begin{tabular}{|l|l|l|l|}
\hline \multirow{2}{*}{ Authors } & \multicolumn{2}{|c|}{ Most antibacterial effect } & \multirow{2}{*}{ References } \\
\cline { 2 - 3 } & Gram-positive bacteria: & Gram-negative bacteria: & \\
\hline Sienkiewicz et al., & - & E. coli & 36 \\
\hline Probuseenivasan et al., & $\begin{array}{l}\text { S. } \text { aureus } \\
\text { B. subtilis }\end{array}$ & $\begin{array}{l}\text { K. pneumonia } \\
\text { E. coli } \\
\text { P. vulgaris }\end{array}$ & 37 \\
\hline ahmady-asbchin et al., & $\begin{array}{l}\text { S. aureus } \\
\text { S. epidermidis }\end{array}$ & $\begin{array}{l}\text { E. coli } \\
\text { P.mirabilis }\end{array}$ & 38 \\
\hline Soltan Dallal et al., & S. aureus & -- & 39 \\
\hline Jafari-sales et al., & S. aureus & $\begin{array}{l}\text { P. aeruginos } \\
\text { E. coli }\end{array}$ & 16 \\
\hline Golshani et al., & S. aureus & $\begin{array}{l}\text { P. aeruginos } \\
\text { E. coli }\end{array}$ & 40 \\
\hline Zakerin et al., & S. aureus & $\begin{array}{l}\text { P. aeruginos } \\
\text { E. coli }\end{array}$ & 41 \\
\hline
\end{tabular}

\section{CONCLUSION}

Rosemary significantly reduces the growth of disease-causing bacteria and slows the growth of bacteria, which increases with increasing concentration of these properties. Given the importance of medicinal plants and their derived metabolites in ensuring the health of human communities and the high economic potential of these plants, as a reliable source of income, a comprehensive and comprehensive plan is needed in developing countries. Part of the agricultural biotechnology research at universities and research institutes is dedicated to identifying, industrializing and optimizing the methods of extracting pharmaceutical metabolites from these plants.

\section{REFERENCES}

1. Cragg, G. M., \& Newman, D. J. (2013). Natural products: a continuing source of novel drug leads. Biochimica et Biophysica Acta (BBA)-General Subjects, 1830(6), 3670-3695.

2. Mukherjee, P. K., Satheesh Kumar, N., \& Heinrich, M. (2008). Plant made pharmaceuticals (PMPs)-development of natural health products from bio-diversity. Indian Journal of Pharmaceutical Education and Research, $42(2), 113$.

3. Jardak, M., Elloumi-Mseddi, J., Aifa, S., \& Mnif, S. (2017). Chemical composition, anti-biofilm activity and potential cytotoxic effect on cancer cells of Rosmarinus officinalis L. essential oil from Tunisia. Lipids in health and disease, 16(1), 190.

4. Jafari-Sales, A., Jafari, B., Sayyahi, J., \& Zohoori-Bonab, T. (2015). Evaluation of antibacterial activity of ethanolic extract of malva neglecta and althaea officinalis 1 . On antibiotic-resistant strains of staphylococcus aureus. $J$ Biol Today World, 4(2), 58-62.

5. Gulluce, M., Sahin, F., Sokmen, M., Ozer, H., Daferera, D., Sokmen, A., ... \& Ozkan, H. (2007). Antimicrobial and antioxidant properties of the essential oils and methanol extract from Mentha longifolia L. ssp. longifolia. Food chemistry, 103(4), 1449-1456. 
6. Jafari-Sales, A., Shahniani, A., Fathi, R., Malekzadeh, P., Mobaiyen, H., \& Bonab, F. R. (2017). Evaluation of Antibacterial Activity of Essential Oil of Ziziphora clinopodioides and Achillea wilhelmsii on Antibiotic-resistant Strains of Staphylococcus aureus. Internal Medicine and Medical Investigation Journal, 2(2), 49-56.

7. Zainab, A., Bhat, R., Acharya, S., Yende, A., PS, P., \& Padyana, S. (2013). Studies on antioxidant and antimicrobial activities of Pajanelia longifolia (Willd.) Schumann. Obesity Research Journal. DOI, 10(2013.756484).

8. Sales, A. J., Shadbad, N. N., \& Kaleybar, V. P. (2015). The Investigation of the Antibacterial effects of Ethanol extract of Cichorium intybus L. on Antibiotic-resistant Staphylococcus aureus strains. Bull Env Pharmacol Life Sci, 4, 161-4.

9. Mobaiyen, H., Jafari Sales, A., \& Sayyahi, J. (2016). Evaluating antimicrobial effects of centaurea plant's essential oil on pathogenic bacteria: staphylococcus aureus, staphylococcus epidermidis, and escherichia coli isolated from clinical specimens. Journal of Fasa University of Medical Sciences, 5(4), 479-487.

10. Tunç, K., Hos, A., \& Gunes, B. (2013). Investigation of antibacterial properties of Cotinus coggygria from Turkey. Pol. J. Environ. Stud, 22(5), 1559-1561.

11. Jafari-Sales, A., \& Bolouri, P. (2018). Evaluation of the antimicrobial effects of Glycyrrhiza glabra 1. on some gram positive and gram negative pathogenic bacteria in laboratory conditions. Jorjani Biomedicine Journal. 6:78-84.

12. Cowan, M. M. (1999). Plant products as antimicrobial agents. Clinical microbiology reviews, 12(4), 564-582.

13. Sales, A. J., Malekzadeh, P., Ebrahimzadeh, M., Kondlaji, K. B., Kaleybar, V. P., \& Dizaji, A. S. (2015). Evaluation of the anti-bacterial effects of ethanolic extract of yarrow (Achillea wilhelmsii) on antibiotic-resistant strains of Staphylococcus aureus. Journal home page: http://www. journalsci. com ISSN, 2322, 326X.

14. Sales, A. J., Bagherizadeh, Y., \& Malekzadeh, P. (2017). Evaluation of the Antimicrobial Effects of Essential Oil of Reseda Lutea L. on Pathogenic Bacteria: Staphylococcus aureus, Staphylococcus epidermidis, and Escherichia coli. Arch Clin Microbiol, 8(3), 1-5.

15. İşcan, G., Kirimer, N., Kürkcüoğlu, M., Başer, H. C., \& DEMIrci, F. (2002). Antimicrobial screening of Mentha piperita essential oils. Journal of agricultural and food chemistry, 50(14), 3943-3946.

16. Jafari-Sales, A., \& Hossein-Nezhad, P. (2019). Antimicrobial effects of Rosmarinus officinalis methanolic extract on Staphylococcus aureus, Bacillus cereus, Escherichia coli and Pseudomonas aeruginosa in laboratory conditions. Journal of Medicinal and Chemical Sciences, 103-108.

17. Sales, A. J. (2014). Evaluation of antibacterial activity of ethanol extract of Lavandula Stoechas L. plant on antibiotic-resistant strains Of Staphylococcus Aureus. Journal of Current Research in Science, 2(6), 641.

18. Mahboubi, M., \& Haghi, G. (2008). Antimicrobial activity and chemical composition of Mentha pulegium L. essential oil. Journal of ethnopharmacology, 119(2), 325-327.

19. Jafari-Sales, A., Rasi-Bonab, F., \& Sayyahi, J. (2019). The Survey on Antimicrobial Effects of Methanolic Extract of Carum Copticum L. on Staphylococcus Aureus, Bacillus Cereus, Escherichia Coli and Pseudomonas Aeruginosa in Laboratory Conditions. Paramedical Sciences and Military Health, 13(4), 19-25.

20. Jafari-sales, A., \& Shadi-Dizaji, A. (2019). Evaluation of Inhibitory Effect of Methanol Extract of Allium Sativum in vitro on Staphylococcus aureus and Escherichia coli. Scientific Journal of Nursing, Midwifery and Paramedical Faculty, 5(1), 61-68.

21. Tajehmiri, A., Issapour, F., Moslem, M. N., Lakeh, M. T., \& Kolavani, M. H. (2014). In vitro antimicrobial activity of Artemisia annua leaf extracts against pathogenic bacteria. Advanced Studies in Biology, 6(3), 93-97.

22. Jafari-Sales, A., Hossein-Nezhad, P., \& Bolouri, P. (2019). Identification of chemical composition of essential oil and evaluation of antimicrobial effects of ethanolic extract of Mentha pulegium on Staphylococcus aureus and Escherichia coli. Health Biotechnology and Biopharma. 3:29-38.

23. Cragg, G. M., \& Newman, D. J. (2002). Drugs from nature: past achievements, future prospects. In Advances in Phytomedicine (Vol. 1, pp. 23-37). Elsevier.

24. Campo, J. D., Amiot, M. J., \& Nguyen-The, C. (2000). Antimicrobial effect of rosemary extracts. Journal of food protection, 63(10), 1359-1368.

25. Bozin, B., Mimica-Dukic, N., Samojlik, I., \& Jovin, E. (2007). Antimicrobial and antioxidant properties of rosemary and sage (Rosmarinus officinalis L. and Salvia officinalis L., Lamiaceae) essential oils. Journal of agricultural and food chemistry, 55(19), 7879-7885.

26. Cheung, S., \& Tai, J. (2007). Anti-proliferative and antioxidant properties of rosemary Rosmarinus officinalis. Oncology reports, 17(6), 1525-1531.

27. Yesil-Celiktas, O., Sevimli, C., Bedir, E., \& Vardar-Sukan, F. (2010). Inhibitory effects of rosemary extracts, carnosic acid and rosmarinic acid on the growth of various human cancer cell lines. Plant foods for human nutrition, 65(2), 158-163.

28. Bakırel, T., Bakırel, U., Keleş, O. Ü., Ülgen, S. G., \& Yardibi, H. (2008). In vivo assessment of antidiabetic and antioxidant activities of rosemary (Rosmarinus officinalis) in alloxan-diabetic rabbits. Journal of ethnopharmacology, 116(1), 64-73.

29. Özcan, M. (2003). Antioxidant activities of rosemary, sage, and sumac extracts and their combinations on stability of natural peanut oil. Journal of medicinal food, 6(3), 267-270. 
30. Randall, R. P. (2012). A Global Compendium of Weeds. Perth, Australia: Department of Agriculture and Food Western Australia, 1124.

31. Peng, Y., Yuan, J., Liu, F., \& Ye, J. (2005). Determination of active components in rosemary by capillary electrophoresis with electrochemical detection. Journal of pharmaceutical and biomedical analysis, 39(3-4), 431437.

32. Khodaei, M. M. (2014). Antibacterial Effect of Allium sativum and Rosmarinus officinalis Essential Oil on Major Mastitis Pathogens in Dairy Cattle.

33. UK Food Standards Agency. (2011). Current EU approved additives and their E Numbers.

34. Andrade, J. M., Faustino, C., Garcia, C., Ladeiras, D., Reis, C. P., \& Rijo, P. (2018). Rosmarinus officinalis L.: an update review of its phytochemistry and biological activity. Future science OA, 4(4), FSO283.

35. Habtemariam, S. (2016). The therapeutic potential of rosemary (Rosmarinus officinalis) diterpenes for Alzheimer's disease. Evidence-Based Complementary and Alternative Medicine, 2016.

36. Sienkiewicz, M., Łysakowska, M., Pastuszka, M., Bienias, W., \& Kowalczyk, E. (2013). The potential of use basil and rosemary essential oils as effective antibacterial agents. Molecules, 18(8), 9334-9351.

37. Prabuseenivasan, S., Jayakumar, M., \& Ignacimuthu, S. (2006). In vitro antibacterial activity of some plant essential oils. BMC complementary and alternative medicine, 6(1), 39.

38. Ahmady, A. S., \& Mostafapour, M. (2018). Anti-bacterial interactions Rosemary (Rosmarinus officinalis) and essential oils of lavender (Lavandula stoechas) on two Grampositive and three Gram-negative bacteria in vitro. Iranian Journal of Cellular and Molecular Researches, 31(2): 177-187.

39. Soltan Dallal, M. M., Ghorbanzade Mashkani, M., Yazdi, M. H., Agha Amiri, S., Mobasseri, G., Mohtasab, A., ... \& Amin Harati, F. (2011). Antibacterial effects of Rosmarinus officinalis on Methicillin-resistant Staphylococcus aureus isolated from patients and foods. Scientific Journal of Kurdistan University of Medical Sciences, 16(1), 7380.

40. Golshani, Z., \& Dawoodi, V. (2013). In vitro study of antimicrobial effects of Rosmarinus officinalis leaf extract against some pathogens. Arak Medical University Journal, 16(77): 82-89.

41. Zakerin, A., Ahmadi, E., Fasihi-Ramandi, M., Abdollahi, S., Molazadeh, A., Jafari, S., ... \& Meshkibaf, M. H. (2015). The Effects of Ecologic Condition on Antimicrobial Activity of Endemic Herbal Extracts in Fars Province. Journal of Fasa University of Medical Sciences, 5(1), 111-119. 